\title{
Effect of training program implemented with a maze-balance board on the developmental areas of preschool children
}

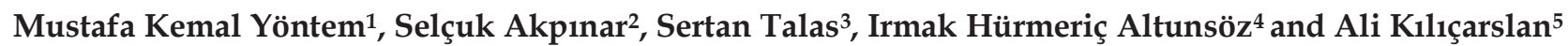 \\ ${ }^{1}$ Nevşehir Hacı Bektaş Veli University, Faculty of Education, Turkey (ORCID: 0000-0001-7620-0971) \\ ${ }^{2}$ Nevşehir Hacı Bektaş Veli University, Faculty of Education, Turkey (ORCID: 0000-0002-9551-237X) \\ ${ }^{3}$ Tokat Gaziosmanpaşa University, Faculty of Education, Turkey (ORCID: 0000-0003-1635-9707) \\ ${ }^{4}$ Middle East Technical University, Faculty of Education, Turkey (ORCID: 0000-0002-8570-196X) \\ ${ }^{5}$ Atakum Guidance Research Center, Turkey (ORCID: 0000-0001-9306-4430)
}

\begin{abstract}
Perceptual development which depends on ability of learning and maturity, is the most important process of mental development. It is commonly believed that the mental development of children is limited due to city life. Children can learn perceptual elements through movement participation. This improves the cognitive development, which triggers kinesthetic, vestibular, balance and tactile input stimuli that contribute to the integration processes in the central nervous system. Children become ready to learn when they develop perceptual and motor skills adequately during maturation and learning. The purpose of this study was to determine the effectiveness of the training program implemented with developed educational material (a maze-balance board) for perceptual and motor skills of preschool children. This study used a pre-post experimental design. Seventeen preschool children from a primary public school in the Middle Black Sea Region of Turkey participated in the study. Random assignment of preschool children to the intervention and control group was done. The children in the intervention group attended a perceptual-training program of 17 to 22 sessions implemented with the maze-balance board. Denver Developmental Screening Test II (DDST II) was used to perform the developmental assessment of children. Mixed Model ANOVA was conducted for statistical analyses. A significant interaction was found in language development and gross motor development, showing that supporting perceptual motor skills in preschool children has significantly contributed to the development of language and gross motor skills in this study.
\end{abstract}

Keywords: Preschool children; Perceptual and motor skills; Developmental areas; Educational material

Article History: Submitted 8 December 202; Revised 7 March 2021; Published online 13 April 2021

\section{Introduction}

Perception is based on learning and maturity. All the information received by the sensory organs is organized, interpreted and explained in the mind. Perceptual development is also considered to be the most important process of mental development (Arı \& Atik, 1987; Bogdashina, 2003). In today's

Address of Corresponding Author

Mustafa Kemal Yöntem, PhD, Nevşehir Hacı Bektaş Veli University, Department of Counseling \& Guidance, Faculty of Education, 50300, Nevşehir, Turkey.

$\triangle$ mustafa.yontem@nevsehir.edu.tr

How to cite: Yöntem, M. K., Akpınar, S., Talas, S., Hürmeriç-Altuniz, I., \& Kilıçarslan, A. (2021). Effect of training program implemented with a maze-balance board on the developmental areas of preschool children. Journal of Pedagogical Research, 5(2), 49-60. http:/ / dx.doi.org/10.33902/JPR.2021068625 
world, the city life tends to restrict the development of children's perceptual motor skills (Tüfekçioğlu, 2008). An early theory proposed by Kephart (1971) emphasizes the importance of perceptual-motor training for all learning activities. Other researchers also hypothesized that movement activity and its correspondence of sensory feedback improve perceptual development, which is a key factor to be successful in other learning areas (Reynolds \& Fletcher-Janzen, 2007). It is a known relation between executive functions and visual-motor maturity (Oliveira et al., 2016). Otoni and Rueda (2019) found correlations between the screening version and the Portuguese and mathematics classes, which indicated that well-developed percept motor maturity tends to be a facilitator to consolidate the contents proposed to school children. Sousa and Rueda (2017) have confirmed the existence of a relationship between perceptual motor skills and attention. Once the children have enough experience and opportunities to develop perceptual and motor abilities, they can be ready to acquire concepts for academic learning.

The development of the perceptual elements also have some effects on cognitive development, with reflexes, kinesthetic, vestibular, balance and tactile input stimuli contributing to the integration processes in the central nervous system (Özer \& Özer, 2016). Among the conditional and coordinative characteristics, agility and equilibrium affect the fluency and coherence of the movements (Erkmen et al., 2007). The quality and quantity of movement experiences of small children are related to the development of perceptual abilities. This perceptual development plays an important role in cognitive functions. The greatest development of perceptual developmental skills is believed to occur in the early years of preschool and primary school. Movement skills are considered an important factor that facilitates the perceptual development of small children (Özer \& Özer, 2016). In their study, Akçınlı Yurdakul et al. (2012) stated that movement education has positive effects on attention and memory. Some researchers emphasize that the application of programs that provide neuromotor maturation at an early age has positive contributions for the entire life (Mengütay, 1997; Özer \& Özer, 2016).

Rosenbaum et al. (2001) stated that intellectual development is associated with perceptual motor development, which is in accordance with Kephart's (1971) stated understanding. The development of perceptual motor skills has a positive impact on reading skills as well (Lachmann, 1960). The relationship between perceptual motor skills with verbal and non-verbal language development and reading skills has been demonstrated in previous studies (Tallal \& Stark, 1982). Merzenich et al. (1966) suggested that motor development is directly related to cognitive development. Perceptual motor activities help to develop basic readiness and academic concepts (Dodson, 2000; Labinowicz, 1980; Schmidt, 1975). This indicates that children become ready to learn when they develop perceptual and motor skills adequately during maturation and learning (Özer \& Özer, 2016). Through this phase, perceptual motor skills can be improved through movement training (Laszlo \& Sainsbury, 1993).

In Turkey, preschool curriculum (MoNE, 2013) has the following statement: "The aim of movement activities is to contribute to the physical, motor, cognitive, language, social and emotional development and self-care skills of the children by developing their basic movement skills. Thus, life-long participation of the children to the physical activities can be ensured. Movement training activities involve the development of physical and motor skills, perceptual motor development and movement skills of children, i.e. displacement, object control and balance skills." This basic education makes an important contribution to the child's physical fitness, perceptual motor development, social-emotional development, development of learning capacity, and the acquisition of good habits in using leisure time positively (Çamliyer, 1999). As it can be seen from the previous studies, perceptual motor training activities are important to develop better concepts for academic learning. Unfortunately, supporting studies are limited in the literature, with some studies having been conducted almost 40 years ago where children tended to spend time outside and had more playground opportunities. Today children do not have the same expectations and opportunities to participate in movement activities. The current study is intended 
to investigate the effect of a training program implemented with new educational material, the maze-balance board on the developmental areas of preschool children.

In this study, the maze-balance board was designed in accordance with the movement training objectives of the Turkish National Education System. The maze-balance board supports the components of perceptual motor development, specifically the vestibular, proprioceptive, and visual systems. The vestibular system is a structure that perceives our linear and angular movements. The proprioceptive system consists of receptors sensitive to gravity, positions, and velocities of body segments, and their contacts to other objects. The visual system is the first system that plans our movements (Deliagina et al., 2007; Winter, 1995). Sensory information from visual, vestibular and proprioceptive systems is used as input (Rothwell, 1994). The maze-balance board is designed so that the participants will perform active and passive movements for this study. The participating children were asked to exhibit passive movements by controlling the balance board, which is a part of the training material. This is accomplished by standing in balance on the balance board, changing the position of the body in order to comply with the oscillations of the balance board. They are also tasked with exhibiting active movements containing different target behaviors independent of the balance board, such as placing a marble in a maze and guiding it to the target point. Such activities help children gain basic motor control skills (Schmidt \& Lee, 2005). Moreover, it is very essential to implement different kind of applications in the fundamental movement phase of the motor development which is considered to be between the 2-6 years old (Gallahue, Ozmun \& Goodway, 2012). Activities including perceptual and motor skills improvement can help children to develop better fundamental movements. We think that the maze-balance board will help to support and improve the components of perceptual motor development. Therefore, the main objective here was to facilitate the active movement of children ( 5 years old) and to create different opportunities for them to acquire advanced motor skills. This is intended to develop kinesthetic, proprioceptive, and vestibular inputs (Snider et al., 2007).

\subsection{The Aim}

The purpose of this study was to determine the effectiveness of the training program implemented with developed educational material for perceptual and motor skills of preschool children. To achieve this purpose, answers to the following hypothesis will be sought:

Hypothesis $1\left(H_{1}\right)$

There is significant difference in the pre-test and post-test language scores of the experimental and control groups.

Hypothesis $2\left(\mathrm{H}_{2}\right)$

There is significant difference in the pre-test and post-test fine-motor development scores of the experimental and control groups.

Hypothesis $3\left(\mathrm{H}_{3}\right)$

There is significant difference in the pre-test and post-test personal -social development scores of the experimental and control groups.

Hypothesis $4\left(\mathrm{H}_{4}\right)$

There is significant difference in the pre-test and post-test gross- motor development scores of the experimental and control groups.

\section{Method}

\subsection{Research Design}

This research was carried out with a pre-post experimental design. In the study, the effect of training program was measured by pre- and post-tests with experimental and control groups. As this is an experimental study, we hypothesized that the training program implemented with the maze-balance board will improve perceptual and motor skills of kindergarten children. 


\subsection{Participants}

A total of 16 children participated in the study. The participants were students in the kindergarten of a primary public school in the Middle Black Sea Region of Turkey. The participants were randomly divided into experimental and control groups. The experimental group consisted of 9 children $\left(\mathrm{M}_{\mathrm{age}}=61 \pm 2\right.$ months -5 boys and $\mathrm{M}_{\mathrm{age}}=61.25 \pm 1.71$ months -4 girls $)$, and the control group consisted of 8 children $\left(\mathrm{M}_{\text {age }}=61.75 \pm 1.5\right.$ months -4 boys and $\mathrm{M}_{\mathrm{age}}=60.5 \pm 1.29$ months -4 girls). Please note that one of the participants in the control group joined the pre-test at the beginning of the study, but moved to another school during the study and is excluded from the study. None of the participants had a chronic illness, any traumatic experience, or a history of inflammatory disease.

\subsection{Instruments}

\subsubsection{Personal information form}

We used a personal information form that included questions on the gender of the participants, the monthly income of their families, presence of chronic diseases, traumatic experience in their past, and inflammatory disease history. This form was filled out by the parents. Parents of the participants were informed about the study and their permissions were obtained. The children's assent to participate in the study were also obtained.

\subsubsection{Denver developmental screening test II (DDST II)}

DDST II is a screening test used for developmental assessment of children from birth to age six. It was developed in 1990 through the revision of the first Denver test (Frankenburg et al., 1992). The adaptation of the DDST II into Turkish was carried out by Anlar and Yalaz in 1996, and it was revised by Yalaz et al. (2011). The Turkish version of DDST II was found as valid and reliable to perform the developmental assessment the children. The test includes four main sub-scales with 134 items: fine motor, gross motor, language development, and personal-social development. The age of the child to be tested is calculated using year, month, and day, and the age line is drawn. The test is conducted using the resulting items: pass, remain, are considered impossible, and rejection. Interpretation of the items is done by scoring as advanced, normal, warning, delay and impossible items. The developmental months of children are presented in terms of total score and each sub-scale score in the test. To be able to use the test, it is necessary to have the test training, so the first, third and fifth authors received this training. Please note that DDST II was used in the pre- and post-tests for both control and experimental groups.

\subsection{Educational Material}

The maze-balance board consists of two different parts as shown in Table 1, the maze and the balance board. Both maze and balance board were made of wood. The maze is designed in an oval shape and has a horizontal width of $50 \mathrm{~cm}$ and vertical width of $30 \mathrm{~cm}$. The balance board is also designed in an oval shape and has a horizontal width of $70 \mathrm{~cm}$ and vertical width of $50 \mathrm{~cm}$. It has two ropes on the horizontal sides to be held by the participant to control the balance during the training. There is also a $40 \mathrm{~cm}$ diameter area for placing the maze in the middle of the balance board. There is a $20 \mathrm{~cm}$ wide and $10 \mathrm{~cm}$ radius piece under the balance board located at its midpoint, which allows testing dynamic balance. While training was completed for each item separately, the end goal was the use of the two pieces at the same time.

\subsection{Procedures}

Before conducting the study, permission from the Ethical Committee was obtained in accordance with the Declaration of Helsinki as amended by the World Medical Association Declaration of Helsinki (World Medical Association, 2013). Once permission was granted, the maze-balance board was developed to support perceptual and motor development of children. Following this, the experimental and control groups were randomly formed from the kindergarten children. A 
seven-stage training program was applied to the experimental group using the maze-balance board. The program was completed in a period of 17 to 22 sessions according to the individual characteristics of the participants. The program was applied to each participant individually as two course-hours per week. No training program was applied to the control group, and the control group attended to its regular training. The pre-test was applied to both groups before starting the program, and the post-test was applied one week after the end of the program. The same program was later applied to the control group so that the control group could benefit from the program.

\subsection{Training Program}

Teaching practices with participants were conducted in a one-on-one training environment. Based on the training environment, a seven-stage training program was prepared by the main researchers. Beginning with the first stage, participants proceeded to each subsequent stage as they accomplished that stage they were in. Each step was studied starting from the first stage. For example, a participant in the third stage repeated the first and second stage before performing the third stage activity. From the fourth stage, the previous stages were randomly repeated and studied. In this way, potential monotony was eliminated. At the end of the program, each participant was able to accomplish all seven stages. The stages are presented in Table 1.

Table 1

Stages of Applied Training Program

Stages Stage Explanations Stage Pictures

Stage 1: Rotating All participants start with rotating marble with hands marble in hand. At this stage, the marble is placed into the maze. The participant continues to rotate the marble randomly in the maze. The elbows are upright and the arms are parallel to the ground for $30 \mathrm{sec}$. The exercise continues until he/she is able to perform the activity for 2 consecutive days.

Stage 2: Playing Participants try to place the marble maze with hands in the maze, with the elbows upright and the arms parallel to the ground. Each participant was allowed two minutes to put the marble in place. The participant who can successfully place the marble 3 times in a row and can repeat it in two consecutive days can proceed to the next stage

Stage 3: Standing Participant learns to stand in balance in balance on the balance board with the support from ropes attached both ends of the balance board, without the maze section. The participant who stays in balance without ropes for 2 consecutive days can proceed to the next stage.
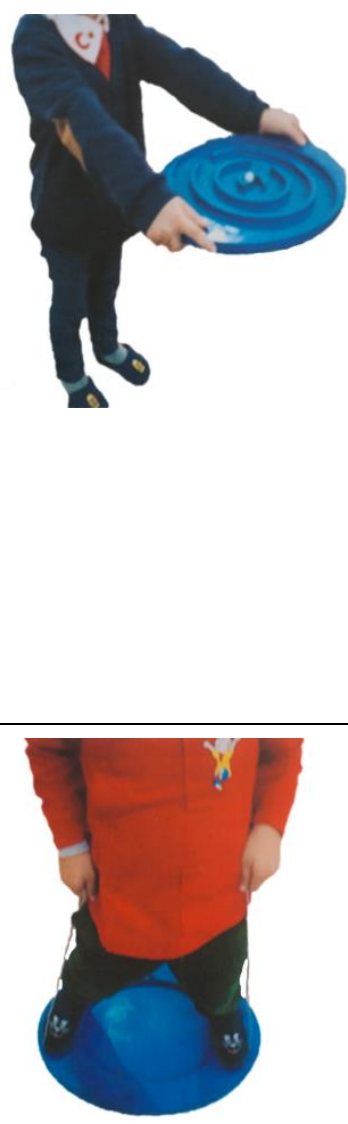
Table 1 continued

Stage 4: Rotating The participant is rotated on the around in full balance board without a rope. The participant who can take 2 full rounds consecutively for 2 days without falling proceeds to the next stage.

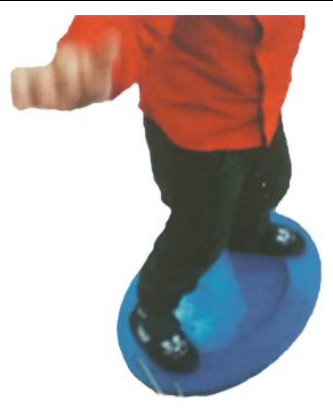

Stage 5: Rotating The maze is attached to the center of marble with feet the balance board and the marble is placed in the maze. With the help of the ropes, participants need to rotate the marble randomly on the balance board. Then, the participant, who succeeds the same action 5 times for $30 \mathrm{sec}$ without the ropes for 2 consecutive days, proceeds to the next stage.

Stage 6: Playing The participant tries to place the maze with feet marble in the maze with the help of the ropes. Then, the participant who can place the marble in the maze for 2 consecutive days without ropes, proceeds to the next stage.

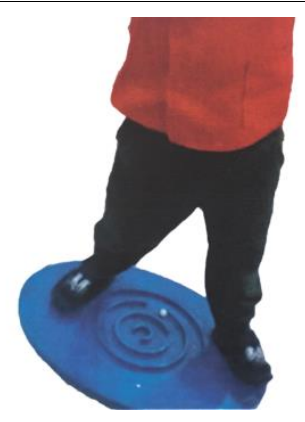

Stage

Standing balancing the maze hand
7: The participant tries to place the in marble in the maze without with disrupting his/her balance on the at balance board while holding the maze. The process continues until the participant places the marble in the maze without disrupting his/her balance three times a day for 2 days.
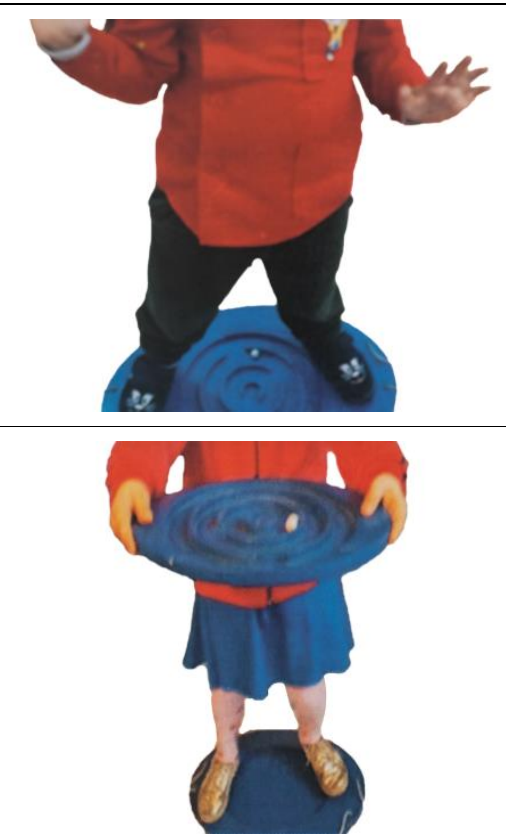

The participant tries to place the marble in the maze without disrupting his/her balance on the balance board while holding the maze. The process continues until the participant places the marble in the maze without disrupting his/her balance three times a day for 2 days.

\subsection{Data Analysis}

Skewness and Kurtosis values range from -2 to +2 for all measures. These values indicate that the data are distributed normally (George \& Mallery, 2010). According to Levene test results, all variants are equal in all measurements except the personal-social test. Data were analyzed using a two-way mixed model ANOVA with group (experimental or control) as a between- subjects factor and measurements (pre- and post-tests) as within-subjects factor. $p<.05$ was accepted as the level of significance in the analysis. The dependent variables were sub-scale scores of the DDST II; language, fine-motor, personal-social, and gross-motor development tests scores. The eta squared 
is reported to describe the effect size. Post-hoc analysis was conducted using Bonferroni adjustment.

\section{Findings}

Participants' pre-test and post-test sub-scale scores in the DDST II are provided in Table 2. While both groups showed an increase on the subscales of DDST II as seen in Table 2, the ratio of improvement from pre- to post-test was substantially higher for the experimental group.

Table 2

Results of Pre-test, Post-test Sub-Scale Scores in The DDST II

\begin{tabular}{|c|c|c|c|c|c|c|}
\hline \multicolumn{7}{|c|}{ Language Development Test } \\
\hline \multirow{2}{*}{ Group } & \multicolumn{3}{|c|}{ Pre-test } & \multicolumn{3}{|c|}{ Post-test } \\
\hline & $N$ & Mean & $S D$ & $N$ & Mean & $S D$ \\
\hline Experimental & 9 & 56.66 & 5.89 & 9 & 70.00 & 8.48 \\
\hline Control & 8 & 56.57 & 4.72 & 8 & 58.28 & 10.79 \\
\hline \multicolumn{7}{|c|}{ Fine-Motor Development Test } \\
\hline \multirow[t]{2}{*}{ Group } & \multicolumn{3}{|c|}{ Pre-test } & \multicolumn{3}{|c|}{ Post-test } \\
\hline & $N$ & Mean & $S D$ & $N$ & Mean & $S D$ \\
\hline Experimental & 9 & 56.66 & 4.09 & 9 & 68.00 & 3.96 \\
\hline Control & 8 & 58.28 & 6.44 & 8 & 66.57 & 10.69 \\
\hline \multicolumn{7}{|c|}{ Personal-Social Development Test } \\
\hline \multirow[t]{2}{*}{ Group } & \multicolumn{3}{|c|}{ Pre-test } & \multicolumn{3}{|c|}{ Post-test } \\
\hline & $N$ & Mean & $S D$ & $N$ & Mean & $S D$ \\
\hline Experimental & 9 & 57.33 & 4.09 & 9 & 71.00 & 3.00 \\
\hline Control & 8 & 52.85 & 9.65 & 8 & 62.71 & 13.02 \\
\hline \multicolumn{7}{|c|}{ Gross-Motor Development Test } \\
\hline \multirow[t]{2}{*}{ Group } & \multicolumn{3}{|c|}{ Pre-test } & \multicolumn{3}{|c|}{ Post-test } \\
\hline & $N$ & Mean & $S D$ & $N$ & Mean & $S D$ \\
\hline Experimental & 9 & 60.66 & 5.55 & 9 & 69.00 & 3.35 \\
\hline Control & 8 & 65.57 & 2.07 & 8 & 70.00 & 6.48 \\
\hline
\end{tabular}

Figure 1 represents the change in children's gross-motor and fine-motor test scores. With a similar approach, the change in personal-social and language test scores is given in Figure 2.

Figure 1

Gross-Motor Development Test and Fine-Motor Development Test Scores

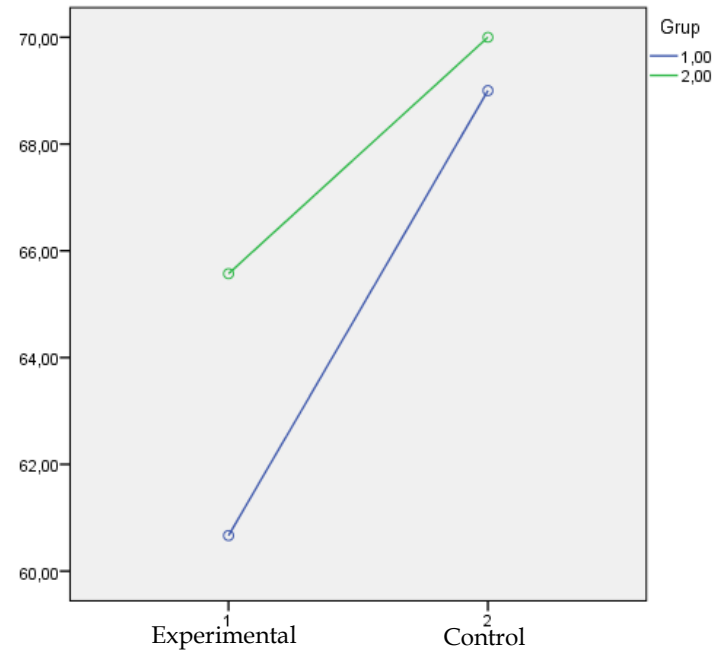

Gross-Motor

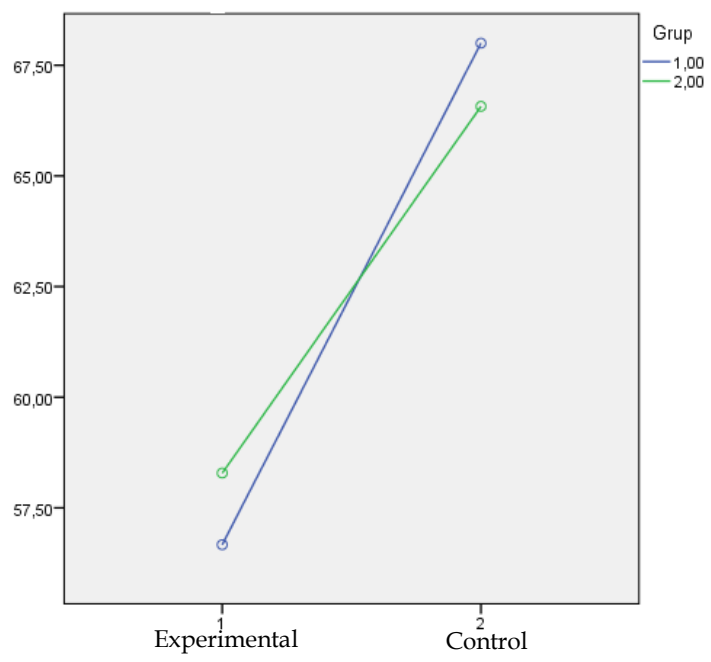

Fine-Motor 
Figure 2

Personal-Social Development Test and Language Development Test Scores

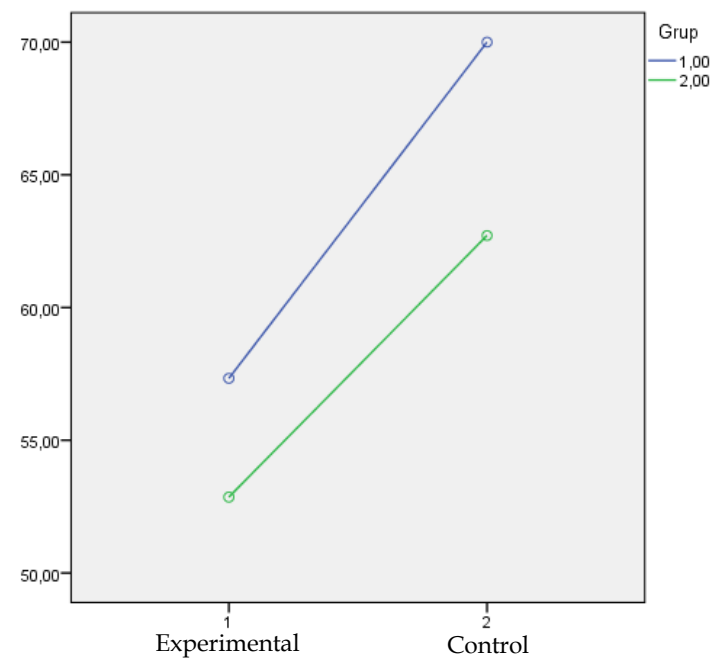

Personal-Social

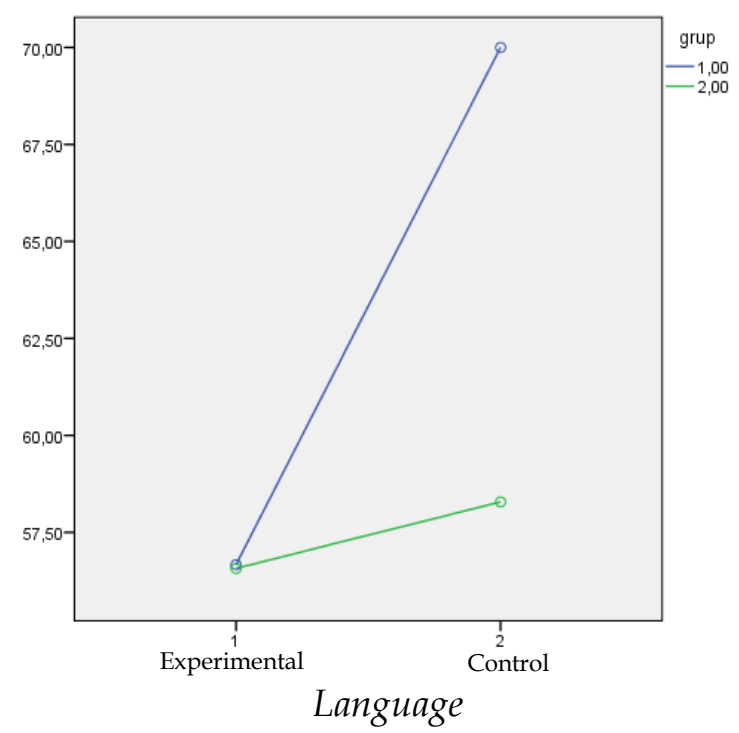

We conducted 4 different two-way mixed model ANOVAs for each sub-scales of DDST II (see Table 3). Analyses address the main effect tests of the groups and measurements. Regarding the main effect of the measurement, it can be said that there is a significant difference between the preand post-test developmental area score averages of the individuals included in the research, regardless of the groups. Interaction between the group and the measurement factors was emphasized since the focus of the research was to test the effectiveness of the training program in increasing the level of development.

Table 3

Repeated Measures ANOVA Results

\begin{tabular}{|c|c|c|c|c|c|}
\hline \multicolumn{6}{|c|}{ Language Development Test $\left(\mathrm{H}_{1}\right)$} \\
\hline & Sum of Squares & Mean Square & & $p$ & $\eta p 2$ \\
\hline \multicolumn{6}{|l|}{ Between Subjects } \\
\hline Group(Experiment/Control) & 274.57 & 274.57 & 3.48 & .08 & .20 \\
\hline Error & 1102.43 & 78.75 & & & \\
\hline \multicolumn{6}{|l|}{ Within Subjests } \\
\hline Measure(PreTest-PostTest) & 445.78 & 445.78 & 10.67 & .00 & .43 \\
\hline Group*Measure & 265.78 & 265.78 & 6.36 & .02 & .33 \\
\hline Error & 584.71 & 41.76 & & & \\
\hline \multicolumn{6}{|c|}{ Fine-Motor Development Test $\left(\mathrm{H}_{2}\right)$} \\
\hline & Sum of Squares & Mean Square & & $p$ & $\eta p 2$ \\
\hline \multicolumn{6}{|l|}{ Between Subjects } \\
\hline Group(Experiment/Control) & .07 & .07 & .001 & .97 & .00 \\
\hline Error & 1024.43 & 73.17 & & & \\
\hline \multicolumn{6}{|l|}{ Within Subjests } \\
\hline Measure(PreTest-PostTest) & 757.79 & 757.79 & 62.14 & .00 & .82 \\
\hline Group*Measure & 18.28 & 18.29 & 1.50 & .24 & .10 \\
\hline Error & 170.7 & 12.19 & & & \\
\hline
\end{tabular}


Table 3 continued

\begin{tabular}{|c|c|c|c|c|c|}
\hline \multicolumn{6}{|c|}{ Personal -Social Development Test $\left(\mathrm{H}_{3}\right)$} \\
\hline & Sum of Squares & Mean Square & & $p$ & $\eta p 2$ \\
\hline \multicolumn{6}{|l|}{ Between Subjects } \\
\hline Group(Experiment/Control) & 272.36 & 272.36 & 2.43 & .14 & .15 \\
\hline Error & 1566.86 & 111.92 & & & \\
\hline \multicolumn{6}{|l|}{ Within Subjests } \\
\hline Measure(PreTest-PostTest) & 998.79 & 998.79 & 64.90 & .00 & .82 \\
\hline Group*Measure & 15.54 & 15.54 & 1.01 & .33 & .07 \\
\hline Error & 215.43 & 15.39 & & & \\
\hline \multicolumn{6}{|c|}{ Gross-Motor Development Test $\left(\mathrm{H}_{4}\right)$} \\
\hline & Sum of Squares & Mean Square & & $p$ & $\eta p 2$ \\
\hline \multicolumn{6}{|l|}{ Between Subjects } \\
\hline Group(Experiment/Control) & 68.64 & 68.64 & 1.81 & .19 & .115 \\
\hline Error & 529.00 & 37.85 & & & \\
\hline \multicolumn{6}{|l|}{ Within Subjests } \\
\hline Measure(PreTest-PostTest) & 320.64 & 320.64 & 52.28 & .00 & .79 \\
\hline Group*Measure & 30.02 & 30.02 & 4.89 & .04 & .26 \\
\hline Error & 85.86 & 6.13 & & & \\
\hline
\end{tabular}

The statistical analysis for the language development test $(F(1,15)=6.36, p<.05, \eta p 2=.33)$ and gross motor development test $(F(1,15)=4.89, p<.05, \eta p 2=.26)$ displayed a significant interaction between group and measurement, which accepted the $\mathrm{H}_{1}$ and $\mathrm{H}_{4}$. Please note that even though both groups improved their gross motor development from pre- to post-test, the experimental group's improvement was substantially more in comparison to the control group. The experimental group had 9 units increase, but control group had only 5 units increase from preto post-test. There were no significant interaction in fine motor development $(F(1,15)=1.50$, $p>.05)$, and personal-social development $(\mathrm{F}(1,15)=1.01, \mathrm{p}>.05)$, which rejected the $\mathrm{H}_{2}$ and $\mathrm{H}_{3}$. These findings indicated that the training program implemented with the maze-balance board for development of perceptual and motor skills has a significant effect on language development and gross motor development.

\section{Discussion and Conclusion}

The objective of this study was to investigate the effect of a training program implemented with the maze-balance board on the developmental areas of preschool children. A significant difference was found between the experimental and control groups in terms of language development and gross motor development. Supporting perceptual motor skills in preschool children has significantly contributed to the development of language and gross motor skills. Previous perceptual-motor training programs revealed similar benefits of the perceptual motor training on the gross motor skills of children. Sajedi and Barati (2014) examined the effects of a two-month long perceptual motor training on motor skills of preschool children and concluded that perceptual-motor activities were effective to support the gross motor skills of typical preschool children. Walters (2005) found similar findings showing that children with developmental coordination disorders (ages 6 to 9) in a perceptual motor development program improved their motor skill competency. It is obvious that perceptual and motor skills are directly related to gross motor skills and perceptual-motor development could be improved through movement training (Laszlo \& Sainsbury, 1993).

It should be noted that a significant increase in the language development of the experimental group compared to the control group should be considered as an interesting finding in this study. This finding is also supported by the related literature. Tallal and Stark (1982) stated that perceptual and motor skills affect verbal and non-verbal language development, and that language 
development is an important predictor of cognitive development. In this context, cognitive development is linked to language development.

There are many studies on the relationship of perceptual motor skills with cognitive development. Rosenbaum et al. (2001) stated that cognitive development is associated with perceptual motor development. Merzenich et al. (1966) suggests that motor development is directly related to cognitive development. The development of perceptual and motor skills has a positive impact on reading skills as well (Lachmann, 1960). Perceptual and motor activities help to develop basic readiness and academic concepts (Dodson, 2000; Labinowicz, 1980; Schmidt, 1975). This can be summarized by saying that children become ready to learn when they develop perceptual and motor skills adequately during the maturation and learning (Özer \& Özer, 2016).

It was previously stated that training specific locomotor tasks may have effects on different centers in the brain and other related functions controlled by this center. Physical activity may improve speech and other sensory functions (Reynolds \& Fletcher-Janzen, 2007). The result of the current study about the effect of the training program on the language development is consistent with the previous studies.

This study also revealed that there were no significant differences in the fine motor skills in the intervention group as parallel to the findings of the research made by Taverna et al. (2020). One possible reason might be that the activities performed with the maze-balance board may not related to fine motor skills. In addition to this there weren't any change in personal-social development of children in the intervention group in this study. Logically any change in personal social development would not be predicted before the study because the children performed the activities individually, not in a group of children. As defined Hersen and Eisler (1976) social skills are the ability to successfully interact with others at school, home and work. As its clear in the definition, in order to improve social skills, the individual must interact with the people around her but in our study the activities performed with maze-balance board individually. So that, If there was an development in social skills in intervention group, we could say that this is not related to the variables of our study.

This study was the first study to design a perceptual-motor program with the maze-balance board in Turkey, and having done so can be seen as a stepping stone in perceptual-motor studies. Further research is warranted in this area, with the number of studies on perceptual-motor development of children should be increased.These findings indicate that increasing the number of programs for the development of perceptual and motor skills in preschool education will contribute positively to the development of children. It is very important in the early education to improve the children's development in different domains. Educators and parents should offer wide range of opportunities to the children to increase their perceptual and motor development. As these domains are very essential to be able to have a healthy life in the following developmental stages, implementing this kind of activities will help children to gain those skills at the suggested developmental period. Thus, we suggest to kindergarten teachers to use materials like developed in this current study to increase children's gross-motor and language development.

\section{References}

Akçınlı Yurdakul, N., Çamlıyer, H., Çamlıyer, H., Karabulut, N., \& Soytürk, M. (2012). The effects of movement education on attention and memory development in the age group of 8 years children. Selçuk University Journal of Physical Education and Sport Science, 14(1), 103-108.

Oliveira, A. L. S. D., Kaiser, V., Azambuja, T. D. O., Mallmann, L. U., Lukrafka, J. L., \& Reppold, C. T. (2016). Visual-motor maturity and executive functions in schoolchildren. Paidéia (Ribeirão Preto), 26(64), 215-223. https://doi.org/10.1590/1982-43272664201609

Anlar, B., \& Yalaz, K. (1996). Denver II Gelişimsel Tarama Testi-Türk çocuklarına uyarlanması ve standardizasyonu [Denver II Developmental Screening Test-Adaptation and standardization for Turkish children]. Meteksan. 
Arı, M. \& Atik, B. (1987). Okulöncesi dönemde duyu eğitimi. Ya-pa 5. Okulöncesi Eğitimi ve Yaygınlaştırılması Seminer kitapçı̆̆ [Sensory education in preschool period. Ya-pa 5th Preschool Education and Dissemination Seminar handbook]. Ya-pa Publishing.

Bogdashina, O. (2003). Sensory issues in autism: different sensory experiences different perceptual worlds. Jessica Kingsley Publishers.

Çamlıyer H, (1999). Eğitim bütünlüğ̈̈ içinde çocuk hareket eğitimi ve oyun [Movement education and play in the integrity of education]. Can Ofset Publishing,

Deliagina T.G, Zelenin P.V, Beloozerova I.N \& Orlovsky G.N. (2007). Nervous mechanisms controlling body posture. Physiology \& Behavior 92, 148-154. https://doi.org/10.1016/j.physbeh.2007.05.023

Dodson, F. (2000). Çocuk yaşken eğilir [Children lean when they are old]. Özgür Publishing.

Erkmen, N., Suveren S., Göktepe, A.S. \& Yazıcıoğlu, K. (2007). The comparison of balance performance of the athletes who are in different branches. The Journal of Physical Education and Sport Sciences, 2(3) 115-122.

Frankenburg, W. K., Dodds, J., Archer, P., Shapiro, H., \& Bresnick, B. (1992). The Denver II: a major revision and restandardization of the Denver Developmental Screening Test. Pediatrics, 89(1), 91-97.

Gallahue, D. L., Ozmun, J. C., \& Goodway, J. (2012) Understanding motor development: Infants, children, adolescents, adults. McGraw-Hill.

George, D., \& Mallery, M. (2010). SPSS for Windows Step by Step: A Simple Guide and Reference, 17.0 update (10a ed.) Pearson.

Hersen, M., \& Eisler, R. M. (1976). Social skills training. In W. E. Craighead, A. Kazdin, \& M. J. Mahoney (Eds.), Behavior Modification: Principles, issues and applications. Houghton Mifflin,.

Kephart, N.C. (1971). The slow learner in the classroom (2nd ed.). Merill Publishing.

Labinowicz, E. (1980). The Piaget primer: Thinking, learning, teaching. Addison-Wesley.

Lachmann, F. M. (1960). Perceptual-motor development in children retarded in reading ability. Journal of Consulting Psychology, 24(5), 427-431. http://dx.doi.org/10.1037/h0046211

Laszlo, J. I., \& Sainsbury, K. M. (1993). Perceptual-motor development and prevention of clumsiness. Psychological Research, 55(2), 167-174. https://doi.org/10.1007/BF00419649

Ministry of National Education [MoNE]. (2013). Milli Eğitim Bakanlı̆̆ı Temel Eğitim Genel Müdürlü̆̆̈̈ Okul Öncesi Eğitim Programı [Ministry of National Education, General Directorate of Basic Education, Preschool Education Program]. http://tegm.meb.gov.tr/dosya/okuloncesi/ooproram.pdf

Mengütay, S. (1997). Okul öncesi ve ilkokullarda haraket gelişimi ve spor [Movement development and sports in preschool and primary schools]. İstanbul.

Merzenich, M., Wright, B., Jenkins, W., Xerri, C., Byl, N., Miller, S., \& Tallal, P. (1996). Cortical plasticity underlying perceptual, motor, and cognitive skill development: Implications for neurorehabilitation. Cold Spring Harbor Symposia on Quantitative Biology, 61, 1-8.

Otoni, F., \& Rueda, F. J. M. (2019). Screening version of Bender test to the assessment of school performance. Psicologia: Teoria e Prática, 21(3), 45-60. https://doi.org/10.5935/1980-6906/ psicologia.v21n3p45-60

Özer, D.S. \& Özer, M.K. (2016). Çocuklarda motor gelişim [Motor development in children]. Nobel Publishing.

Reynolds, C.R. \& Fletcher-Janzen, E. (2007). Encyclopedia of special education (3rd ed.). John Wiley \& Sons, Inc. Hoboken.

Rosenbaum, D. A., Carlson, R. A., \& Gilmore, R. O. (2001). Acquisition of intellectual and perceptual-motor skills. Annual Review of Psychology, 52(1), 453-470. https://doi.org/10.1146/annurev.psych.52.1.453

Rothwell, J. (1994). Control of human voluntary movement. Chapman \& Hall.

Sajedi, F., \& Barati, H. (2014). The effect of perceptual motor training on motor skills of preschool children. Iranian Rehabilitation Journal, 12(1), 14-17.

Schmidt, R. A. (1975). A schema theory of discrete motor skill learning. Psychological Review, 82(4), 225-260. https:// doi.org/10.1037/h0076770

Schmidt, R.A. \& Lee, T.D. (2005). Motor control and learning (4th ed.). Human Kinetics Services.

Snider, L., Korner-Bitensky, N., Kammann, C., Warner, S., \& Saleh, M. (2007). Horseback riding as therapy for children with cerebral palsy: Is there evidence of its effectiveness?. Physical \& Occupational Therapy in Pediatrics, 27(2), 5-23.

Sousa, V. de, \& Rueda, F. J. M. (2017). The Relationship between perceptual motor skills and attention. Paidéia (Ribeirão Preto), 27(66), 24-32. https://doi.org/10.1590/1982-432727662017046201704

Tallal, P. \& Stark, R. E. (1982). Perceptual/motor profiles of reading impaired children with or without concomitant oral language deficits. Annals of Dyslexia, 32(1), 163-176. https://doi.org/10.1007/BF02647960 
Taverna, L., Tremolada, M., Tosetto, B., Dozza, L., \& Renata, Z. S. (2020). Impact of psycho-educational activities on visual-motor integration, fine motor skills and name writing among first graders: a kinematic pilot study. Children, 7(4), 27. https://doi.org/10.3390/children7040027

Tüfekçioğlu, E. (2008). The effect of perceptual-motor development programs on balance and quickness in preschool children aged 4-6 years. International Journal of Human Sciences, 5(2), 2-11

Walters, Y. (2005). The effects of a perceptual-motor development program on children with developmental coordination disorder (Unpublished doctoral dissertation). University of Stellenbosch, Stellenbosch.

Winter, D. A. (1995). Human balance and posture control during standing and walking. Gait \& Posture, 3(4), 193-214. https://doi.org/10.1016/0966-6362(96)82849-9

World Medical Association (2013). World Medical Association Declaration of Helsinki: ethical principles for medical research involving human subjects. JAMA, 310(20), 2191-2194. https://doi.org/10.1001/jama.2013.281053

Yalaz, K, Anlar, B, \& Bayoğlu, B. (2011). Denver II Gelişimsel Tarama Testi El Kitabı Türkiye Standardizasyonu [Denver Developmental Screening Test II Standardization Handbook Turkey]. Anıl Grup Publishing. 